\title{
Swiss medical technology industry gobbling up market share
}

I t's rapidly becoming a global brand unto its own: Swiss medtech, as industry advocates call it.

In scant decades, Switzerland has bulled its way on the global medical technology market, using, it seems, an approach that has long been championed by Dr. Arthur Carty, Canada's former national science and technology advisor and the former president of the National Research Council of Canada.

Carty calls it "cluster" strategy. It essentially involves assessing the economic strengths and capabilities of a region and then bringing together "the resources and the people and the programs required to make it happen."

The Swiss appear to have mastered it.

With the clock ticking on their watch industry in the late 1970s because of a glut of cheaper, digital Japanese watches, the Swiss timepiece and mechanical engineering sectors were flailing about for options.

Initially, they sort of fell into medical technology. "It wasn't a conscious shift. It just sort of happened," explains Patrick Dümmler, managing director for Medtech Switzerland, who undertook an economic analysis of the industry for his doctorate.

But as the shift occurred, a combination of government technology development programs, a talented and welleducated labour pool, a supportive academic community and favourable tax rates have combined to make Swiss medtech one of the fastest growing industrial sectors in the country, with an average growth rate of $6 \%-8 \%$ per year for each of the past 15 years. From 2006 and 2008, for example, it grew between $25 \%$ and $30 \%$. The global financial crisis of 2008 caused a brief letdown but by 2010 and 2011, the growth rate had bounced back to $10 \%$, according to an industry survey (www .medtechswitzerland.com/en/index.php ?section=downloads).

Sales in the medical technology sector topped 22.9 billion Swiss francs in 2008 , or about $2 \%$ of the country's

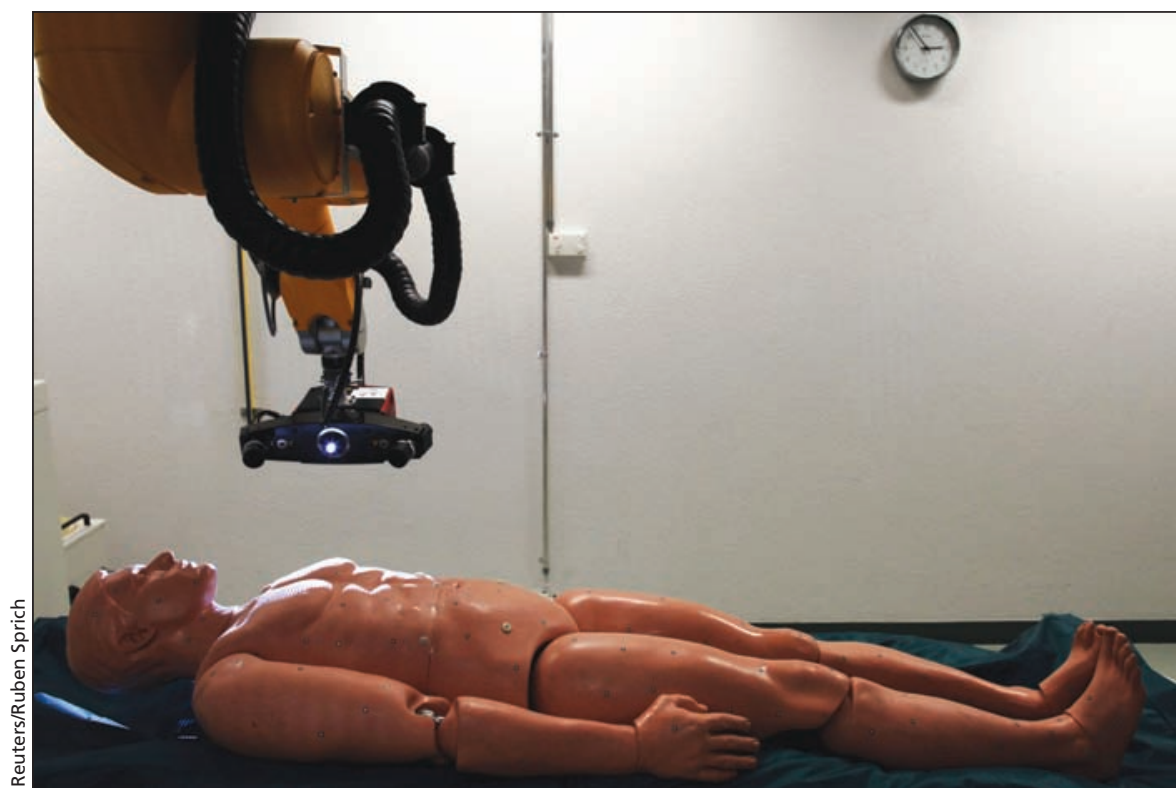

A dummy lies on a stretcher of an optical 3D and a magnetic resonance scanner during a demonstration of a "virtopsy," an autopsy conducted without cutting open a body. The technology was developed by Michael Thali, a professor at the University of Bern. It has been used since 2006 to examine all sudden deaths or those of unnatural causes in the Swiss capital, and can detect up to $80 \%$ of causes of death.

gross domestic product, the highest percentage of any country, according to the industrial consulting firm Roland Berger and Deloitte.

The Swiss medtech sector is now comprised of about 700 companies, employing 49000 people in the production of such products as dental and orthopedic implants, urinary infection diagnostics, surgical tools, sterilization products for the health care sector, electrocardiographs and precise ophthalmology measuring tools.

The sector's growth was aided by what appears to be a commitment to innovation within the general populace of 7.8 million. Switzerland was ranked as the globe's fourth most innovation nation by the Institute for Management Development (www.imd.org/research /publications/wcy/index.cfm). It also is Europe's most innovative nation, according to a report prepared for Pro Inno Europe, a cluster of 27 European Union members, by the Maastricht Economic and Social Research and Training Centre on Innovation and Technology (www.proinno-europe.eu/page/european -innovation-scoreboard-2009).

A combination of factors have contributed to the sector's growth, says Gerard Bauer, head of global operations for Straumann, a global leader in dental implants and restorative dentistry. The sector has flourished because of "highly educated and skilled people ... worldclass research, and the strong partnerships between universities, colleges of applied technology and the industry."

Among the partners have been such research centres as the Zurich-based Swiss Federal Institute of Technology, which is consistently ranked the top university in continental Europe in The Times higher education world university rankings (www.timeshighereducation .co.uk/world-university-rankings).

The sector has also benefited from government programs that aimed to bolster commercialization. Switzerland has "a mixed bag of organizations" that support medtech initiatives, says Sheena Bethell, an ex-pat Canadian who works as a business consultant for 
the Basel Area Economic Promotion, one of several regional economic promotion organizations funded by local cantonal governments and business organizations. In some cases, the cantons provide some funding for promotion work such as attending international events.

"We offer a full-service, one-stop shopping program for companies coming here," said Jean-Frédéric Berthoud, a director in the economic development office for the Canton (province) of Vaud, during a presentation on BioAlps at the École Polytechnique Fédérale de Lausanne. "We first discuss the business plan for the company, help it prepare all the documents for tax rulings and will coach them on all the different steps and phases of the processes."

A benevolent tax system is also helpful, he added. "We have federal, Canton and municipal taxes. A standard company is taxed at $23 \%$ to $24 \%$, at all levels [combined]. But if it fulfills certain conditions it can go down to $9 \%$ to $10 \%$."
Switzerland also has one of Europe's lowest value-added taxes at 7.6\%.

Medtech companies can also benefit from the national, government-funded CTI Medtech (Commission for Technology and Innovation), established to promote innovation and competitiveness. In the past 12 years, the commission has provided nearly 250 million Swiss francs to 235 projects.

That primarily involves funding for collaborative ventures with universities and other research organizations, says Philippe Ugnat, the Toronto, Ontariobased director of Canadian operations for the Economic Development Agency of the Canton of Vaud. "The money from the CTI goes to the university to cover part of the costs of the R\&D [Research and Development]. Any discovery or intellectual property that is generated by the R\&D collaboration is owned $100 \%$ by the company and there is no requirement to pay royalties to the university. This is particular to Switzerland and not something we see in North America."
Switzerland labour laws also appear to be an asset. They "are somewhat liberal here compared to other countries," says Peter Höst, CEO of Medela AG, which manufacturers advanced breastpumps and breastfeeding accessories. "None of our employees here are unionized and that gives us flexibility."

The industry exports about $70 \%$ of its products. "We were always forced to look outside the country for markets, to be international, if we wanted to survive," Dümmler says. "And to succeed internationally we had to offer the world the highest top-end, quality possible."

"A lot of companies don't have their roots here but they still use Switzerland as a production site. 'Swiss Made' has always been a symbol of quality," he adds. "When manufacturing medical devices this can become an important consideration," he adds. "They want it stamped on their products, and we take advantage of that as much as we can." Paul McLaughlin, Lausanne, Switzerland

CMAJ 2011. DOI:10.1503/cmaj.109-3742 